\title{
INVESTIGATION OF MECHANICAL BEHAVIOUR OF BRICKS WITH TREATED RED MUD RESIDUE ADDITIVES
}

\author{
Noémi Szász \\ PhD student, University of Miskolc, Institute of Environmental Management \\ 3515 Miskolc, Miskolc-Egyetemváros, e-mail: hgszn@uni-miskolc.hu \\ István Székely \\ assistant research fellow, University of Miskolc, Institute of Environmental Management \\ 3515 Miskolc, Miskolc-Egyetemváros, e-mail: hgsszi@uni-miskolc.hu \\ Balázs Kovács \\ honorary university professor, University of Miskolc, Institute of Environmental Management \\ 3515 Miskolc, Miskolc-Egyetemváros, e-mail: modflow@gmail.com
}

\begin{abstract}
Millions of tons of red mud are currently generated in the world as a by-product of aluminium production. The storage of this red mud causes both technological and environmental problems for professionals. Therefore, an important area of research is to prioritize research into the use of red mud as a secondary raw material. Several studies have already been carried out on the subject, either on the utilization of the metal content of red mud or even on its use in building industry, but economical, industrial-scale application has not yet been achieved in either case. The aim of the present research is to develop an economical technology base for the use of red mud as a secondary raw material in the brick industry.
\end{abstract}

Keywords: brick production, clay, load capacity, red mud

\section{Introduction}

During the production of aluminium, an intermediate material, alumina, is produced from the mined bauxite (Schwarz, 2004), and red mud is a by-product of this alumina production, a strongly alkaline (Power, et al. 2011), fine-grained material. Its characteristic reddish colour is caused by its high iron oxide content (Németh, 2013). In most parts of the world, the so-called Bayer process (Figure 1) is currently used to produce alumina (Haupin 2011).

The essence of the process is that during the process the alkali is used (for economic reasons) in a cycle-like manner, so it is used not in one but in several operational phases. In the so-called digestion stage, the aluminium content of the bauxite is dissolved from the ground bauxite at a high temperature using sodium hydroxide (Tabereaux, et al., 2014).

After the resulting solution has cooled and precipitated aluminium hydroxide is crystallized from it, then sodium hydroxide is recovered by evaporation. Mixtures of other residual minerals (red mud) are highly alkaline wastes that require special storage (Akcil, et al., 2017). Elements found in bauxite in red mud can also be observed, such as aluminium-oxide $\left(\mathrm{Al}_{2} \mathrm{O}_{3}\right)$, hematite $\left(\mathrm{Fe}_{2} \mathrm{O}_{3}\right)$, silica $\left(\mathrm{SiO}_{2}\right)$, titanium dioxide $\left(\mathrm{TiO}_{2}\right)$, calcium oxide $(\mathrm{CaO})$, water $\left(\mathrm{H}_{2} \mathrm{O}\right)$, etc. (Wang, et al. 2008; Lima, et al., 2017). 


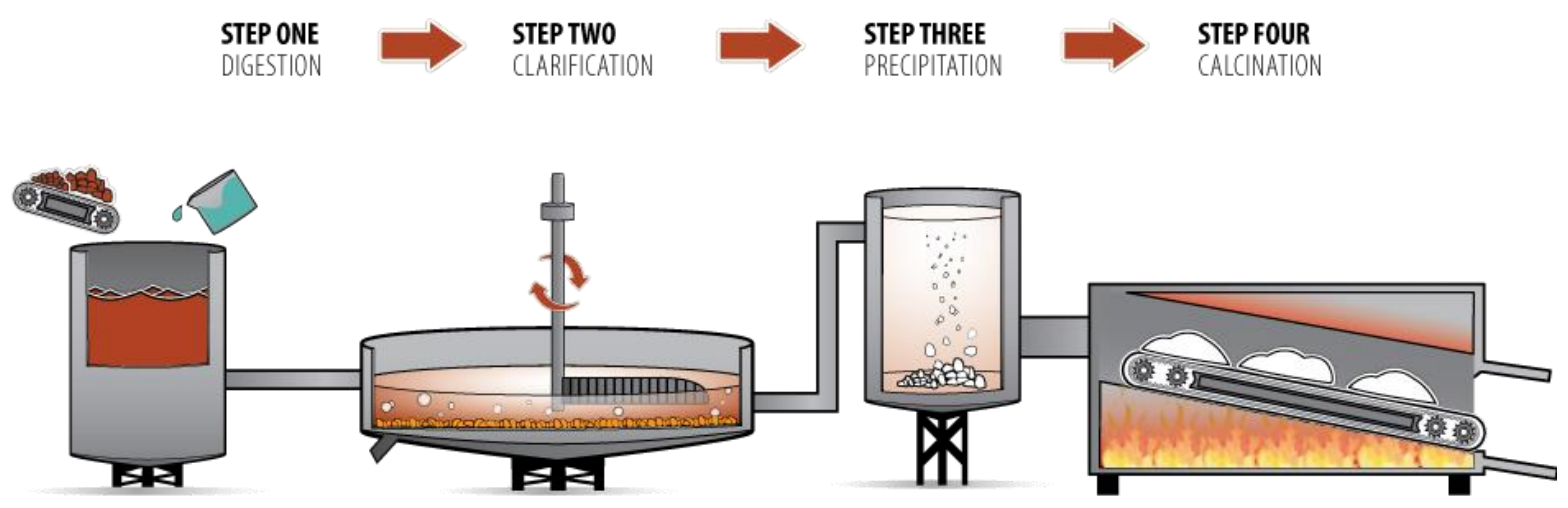

Figure 1. The schematic figure of the Bayer process (https://aluminium.org.au)

\section{Materials and Methods}

In order to produce the manufactured specimens (bricks), the brick-making processes in a more conventional sense must be examined and interpreted. The foundations of brick manufacturing have not changed over time, but technological advances have made contemporary brick factories significantly more efficient and improved the overall quality of products (Shakir and Mohamed, 2013). A better knowledge of the raw materials and their properties, better control of combustion, better furnace design and more advanced mechanization have all contributed to the development of the brick industry. Clay is one of the most abundant natural mineral raw materials on earth. Such clays must have a plasticity that allows them to be formed when mixed with water; they must have sufficient wet and air-dried strength to retain their shape (Dalkılıç and Nabikoğlu, 2017). Although the principles of production are quite uniform, each production plant adapts its production to suit the specific raw materials and operation. Essentially, a brick is made by mixing ground clay with water, shaping the clay into the desired shape, and then drying and firing (https://gobrick.com).

The strength of bricks is affected by the properties of the clay, the method of production and the degree of firing. For a given clay and production method, higher compressive strength values are associated with higher combustion temperatures.

\subsection{Pre-treatment of red mud}

Prior to the preparation of the brick-making processes, the red mud sample underwent a multi-stage treatment (Figure 2).

\subsubsection{Acidic extraction of the red mud}

Regarding the processing processes of red mud, in previous studies, the so-called acid extraction phase has been established, during which valuable raw materials (e.g., scandium) are extracted. In the present case, as the first step of the extraction, sulfuric acid (10 litres) and distilled water (40 litres) was added to the red mud $(10 \mathrm{~kg})$. After extraction, a significant portion of the red mud matrix remains as a socalled "extraction residue". The substance, although acidic, will not affect use in the subsequent phases. 
The resulting mixture, after adequate mixing, was set aside to allow the dissolution processes to take place (also, the process involves intense gas formation, with which direct contact should be avoided).

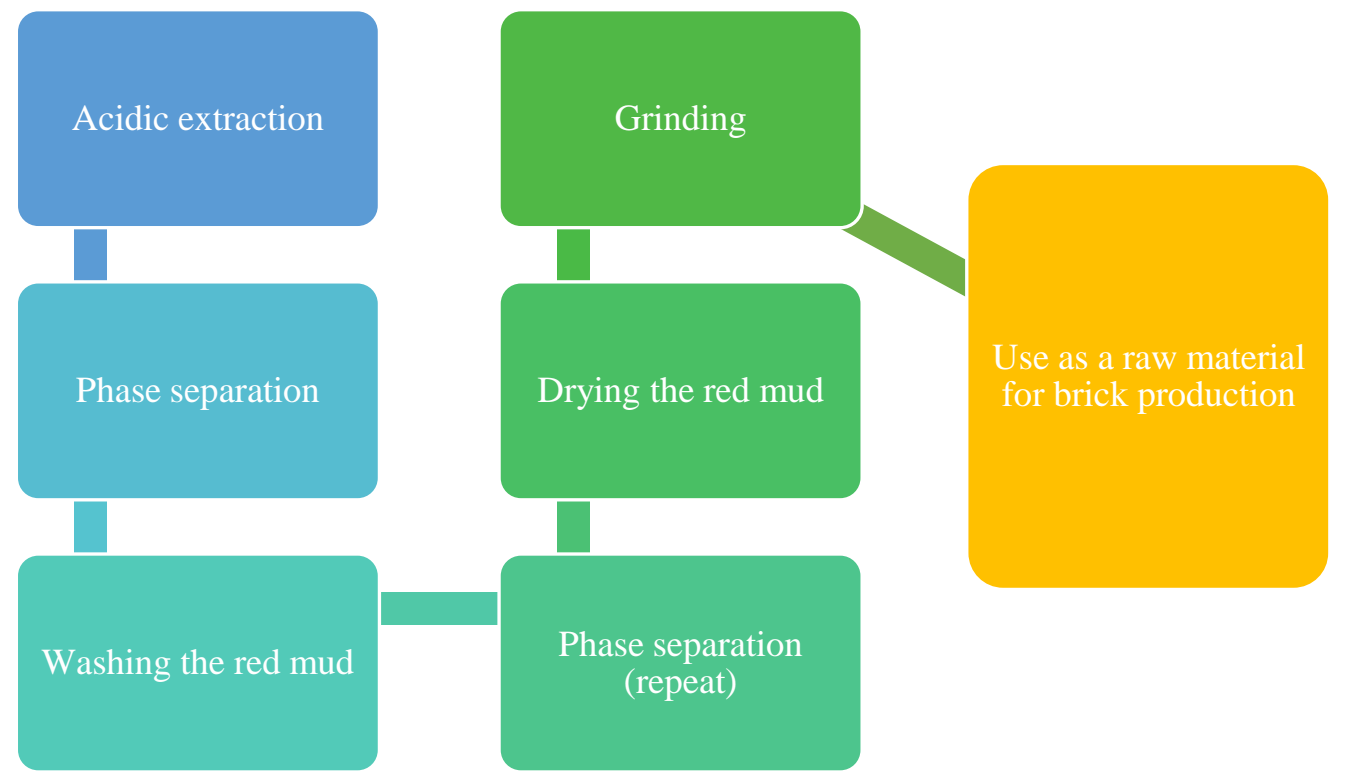

Figure 2. Flow chart of steps applied during red mud pre-treatment

After settling, the red mud matrix and the acidic liquid were separated using a vacuum pump. The red mud matrix was then washed twice with 30-30 litres of distilled water. As mentioned earlier, the matrix remaining during the process is acidic, so it is necessary to neutralize it. The easiest way to achieve this is to add lime powder stepwise to the matrix. The essence of the stepwise neutralization is that the $\mathrm{pH}$ of the red mud was continuously checked during the addition and the lime powder was added accordingly.

\subsubsection{Grinding of the red mud}

The red mud matrix remaining for brick production was heated (after neutralization) at $105^{\circ} \mathrm{C}$ for 24 hours to constant mass. This step is an important aspect of the preparation processes because previous studies have shown that when the red mud suspension is used in wet form, the water content required for brick production cannot be achieved.

After drying, the red mud matrix compacted due to the added limestone powder and heat, so it became necessary to pre-grind the material, which will make the particle size of the raw materials used almost the same. The pre-grinding of the materials was performed with the help of a hammer crusher (Figure 3) from the University of Miskolc, Institute of Raw Material Preparation and Environmental Processing. Hammer crushers and mills utilize the kinetic energy of the grains for shredding work. The material sent to the equipment shatters when it collides with the hammers rotating at high peripheral speed $(20-60 \mathrm{~m} / \mathrm{s})$, and then breaks further by beating the wall of the crusher. The hammers shred the material until the it leaves through the outlet (Faitli, et al., 2017). 


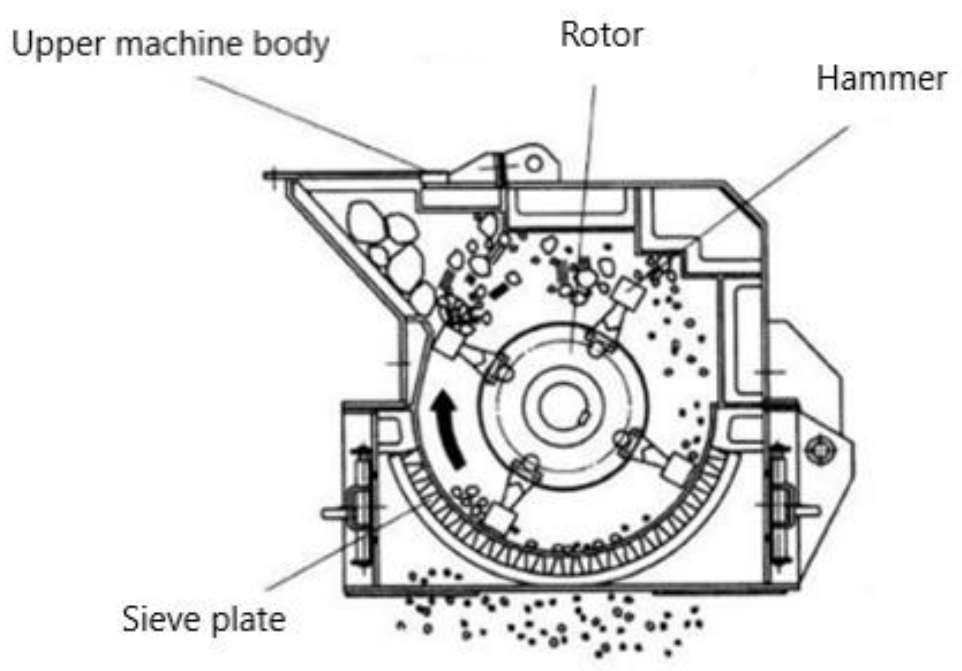

Figure 3. Lateral section of the hammer crusher (Faitli, et al., 2017)

In addition to red mud, clay was also used as the raw material for the bricks. Thus, the grinding was carried out not only on the red mud (Figure 4), but also on the clay (Figure 5), as compaction was observed in this case as a result of dehydration. After grinding, a re-drying phase followed in order to be able to precisely adjust the water content of the brick.

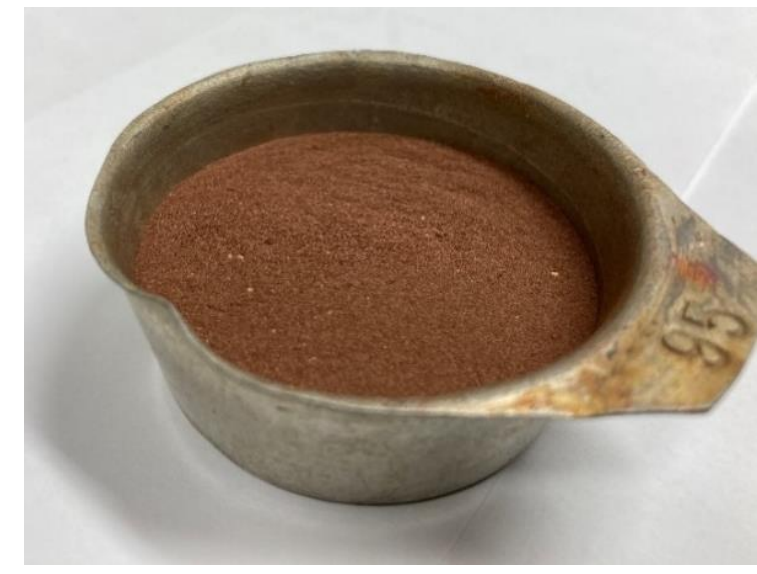

Figure 4. Red mud in ground, dried state

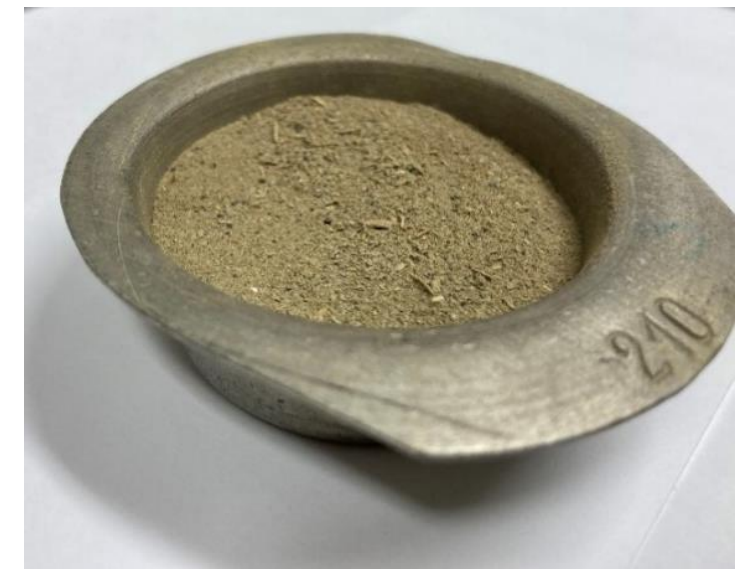

Figure 5. Clay in ground, dried state

\subsubsection{Tools used in the manufacture of bricks}

For laboratory measurements, as well as to produce test specimens, a special set of tools was needed, which can be provided with the existing devices, instruments, and individual device development solutions. 
For the specimens to be shape-retaining, it was necessary to design a uniform mould (Figure 6) made for this purpose, which was cut from stainless steel tubes. Parameters of the mould:

- diameter $=28,00 \mathrm{~mm}$

- height $=50,00 \mathrm{~mm}$

In terms of size and shape, the choice was made to design specimens of the size required to perform compressive strength tests. The mixtures of materials of different compositions, filled into the mould, were first compressed by hand. This was necessary in order to load the maximum amount of material, thus minimizing the gaps and increasing the degree of compression and consolidation. For manual pressing, a tool manufactured for this purpose was used (Figure 6).

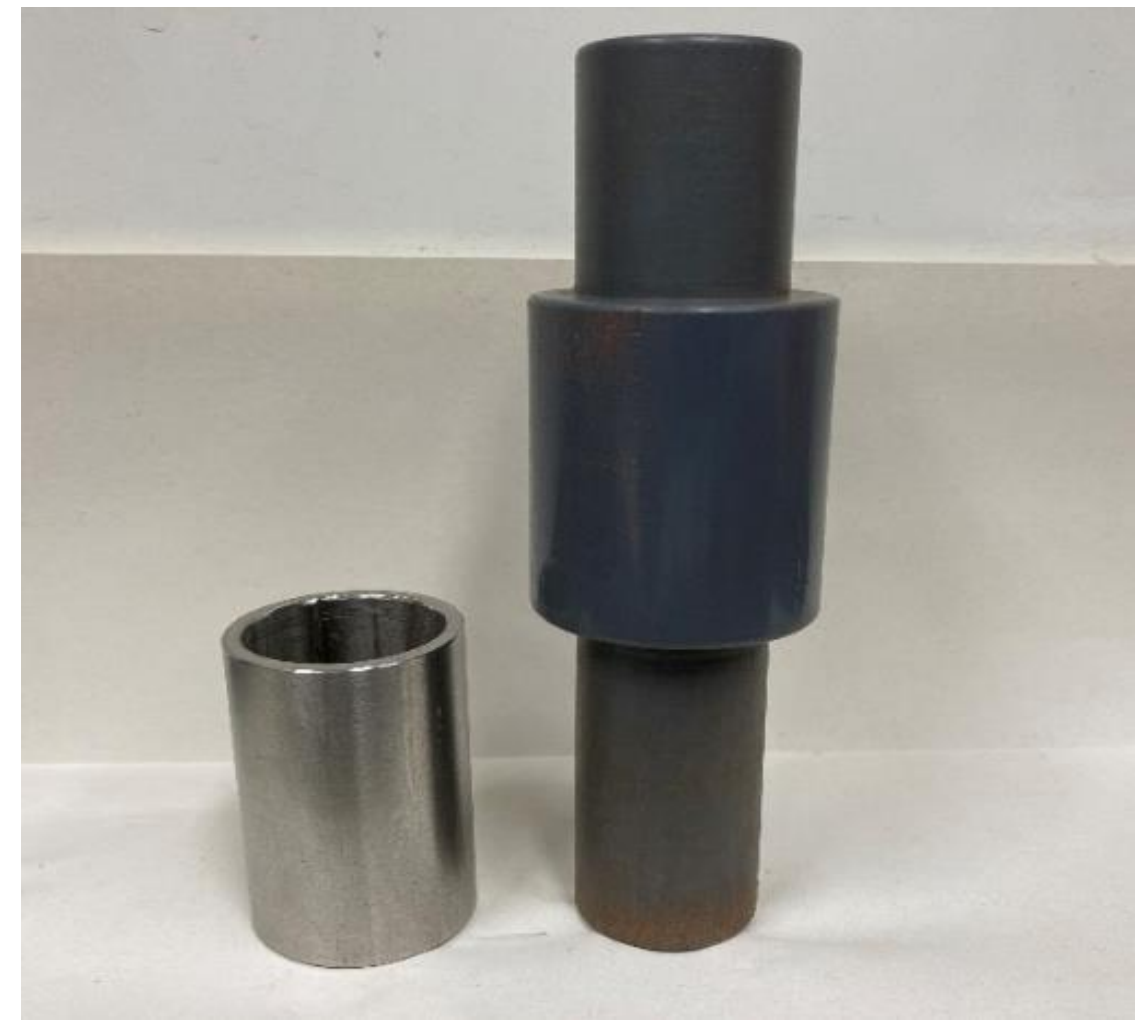

Figure 6. The stainless steel mould compared to the manual compression device

Hiba! A hivatkozási forrás nem található. shows the device and the steel mould compared to each other. The height of the mould is the same as that of the device, and that their inner diameter is the same, for the consideration that it is suitable not only for compacting the sample but also for squeezing it out of the mould.

After mechanical loading of the moulds, the specimens were consolidated using a hydraulic press. The use of this was justified in order to keep the texture of the mixtures homogeneous. Drainage of pore water from the samples was solved using a filter plate (Figure 7). After consolidation, the steel moulds were removed, and the bricks were dried for 2 days at room temperature until they reached the air dry state. 


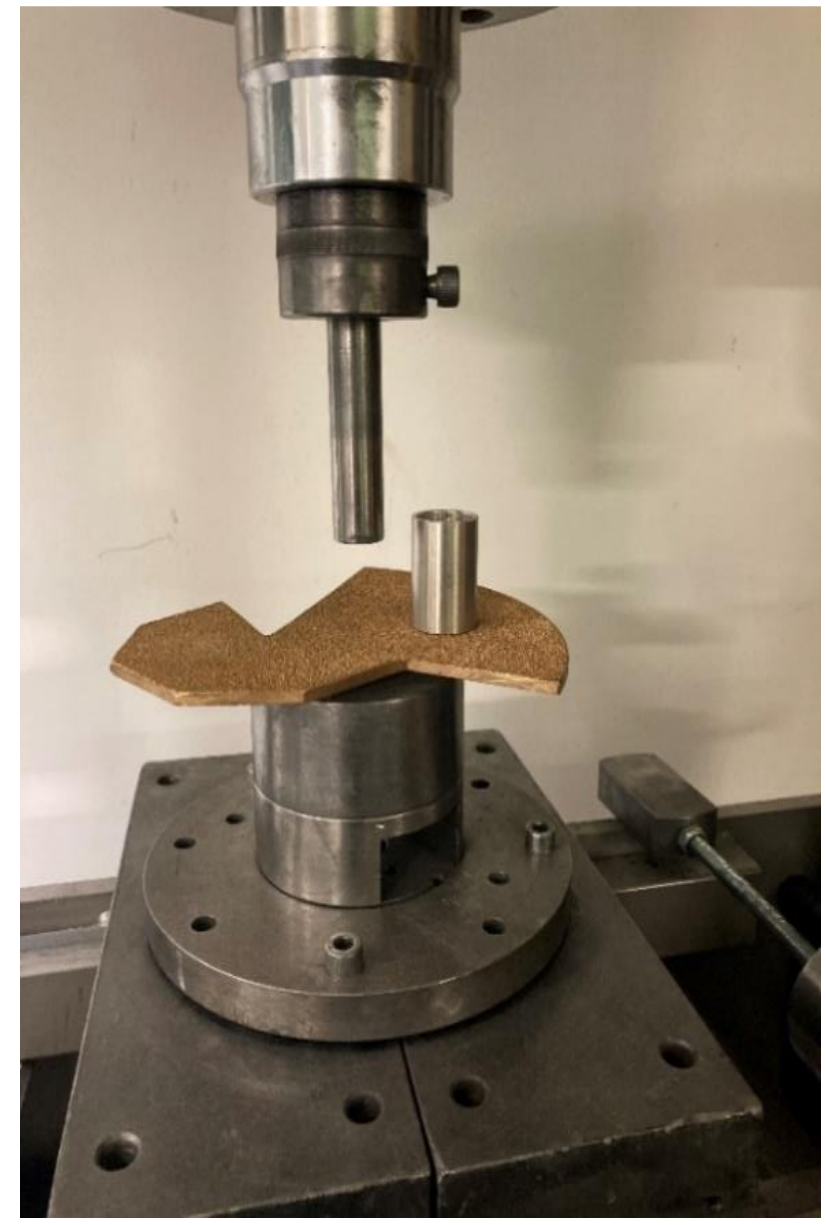

Figure 7. Mould and filter plate placed in the press

After 2 days, the samples were transferred to the furnace where they were fired at a constant temperature of $1000{ }^{\circ} \mathrm{C}$ for 4 hours.

\subsubsection{Impact assessment between compaction modes}

In the first phase of the studies, it is necessary to examine the difference between the different types of compaction work (manual or mechanical). The effect of compaction work on the structural properties of the specimens is illustrated by the two samples of the same composition but exposed to different compaction work shown in Figure 8. Test specimens made by manual pressing (above) and hydraulic pressing (below).

It can be clearly seen that manual compaction was not sufficient to homogenize the texture of the specimens. In contrast, the consolidation with the press made the specimens reproducible, thus achieving the same texture within a series. $(\mathrm{P}=1$ bar; $\mathrm{T}=1$ hour). Differences occurred for all series, regardless of the composition of the samples. 

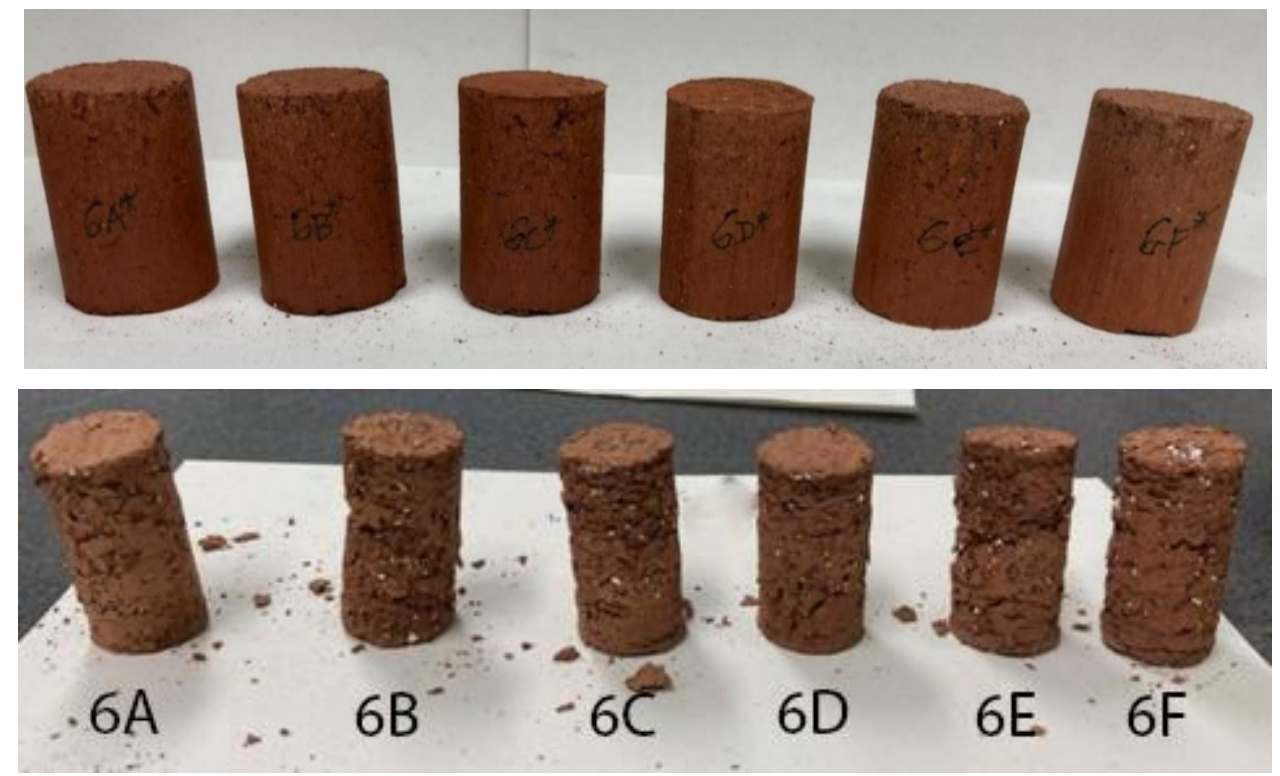

Figure 8. Test specimens made by manual pressing (above) and hydraulic pressing (below). Both series had the same composition (50\% red mud, $50 \%$ clay).

\section{Results and conclusions}

By compressive strength of a body is meant its resistance to forces acting in the opposite direction in the longitudinal axis of the body (in other words, the resistance of materials to compressive force). The stress value at which a material fails is called the compressive strength of the material (Szakács, et al., 2012).

In the first round, clay and red mud were used as a component for the bricks, and their proportions were varied for each series (Figure 9), which means that the proportion of red mud added to the bricks varied between 0 and $50 \%$.

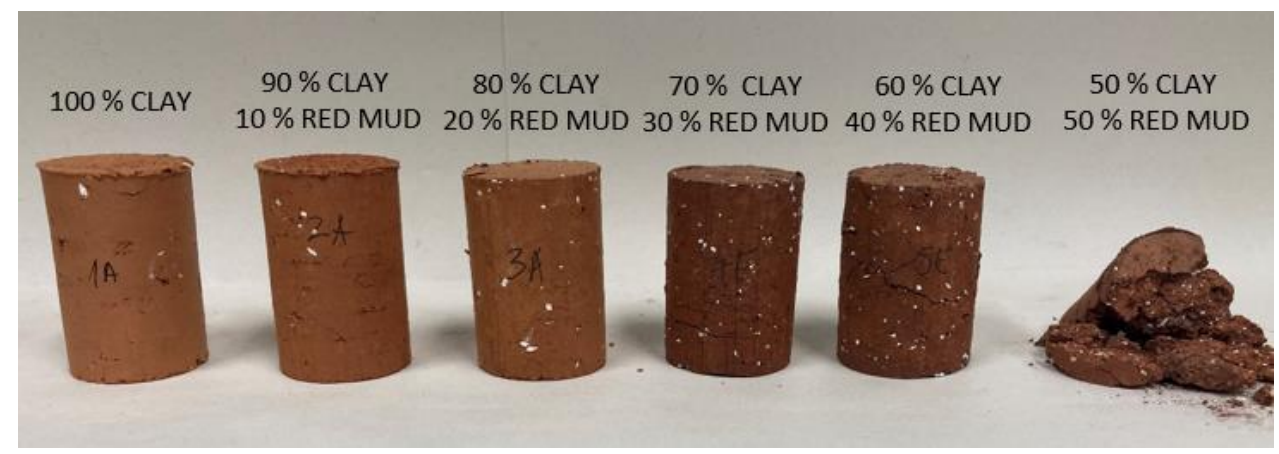

Figure 9. Bricks of different compositions

Each series contains 6-6 specimens, three of which were randomly selected, and their compressive strength was measured. An Instron 3365 universal testing machine (Figure 10) was used for compressive 
strength tests. The samples placed in the machine were loaded with a pre-set load step of $250 \mathrm{~N} / \mathrm{min}$. The steps and control functions could be changed using the software provided with the equipment. In addition to the control, the software recorded force, displacement, and time values. The tests were performed until the specimens were destroyed (Figure 11).

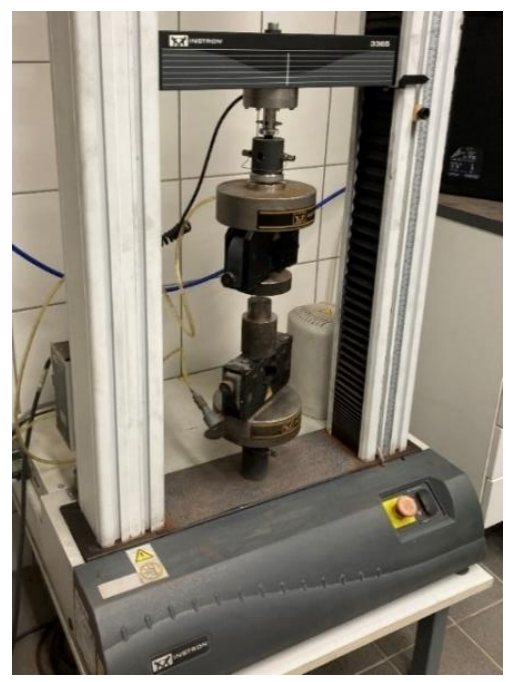

Figure 10. Instron 3365 universal testing machine

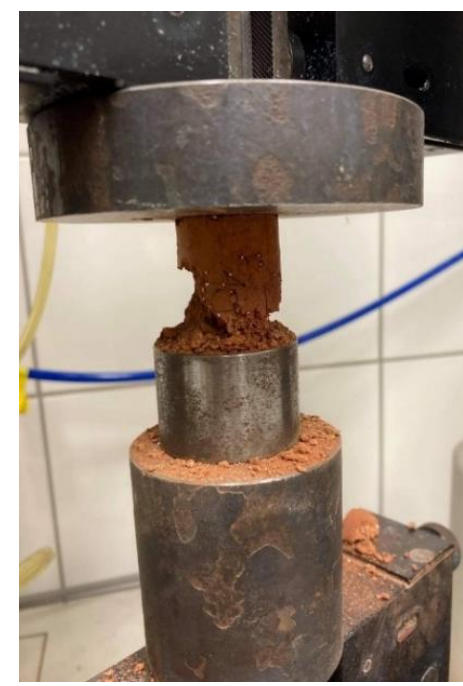

Figure 11. Specimen loaded to failure

The data measured by the instrument were plotted as a function of force-displacement, from which the maximum load capacity of a given specimen up to failure can be read (Hiba! A hivatkozási forrás nem található.).

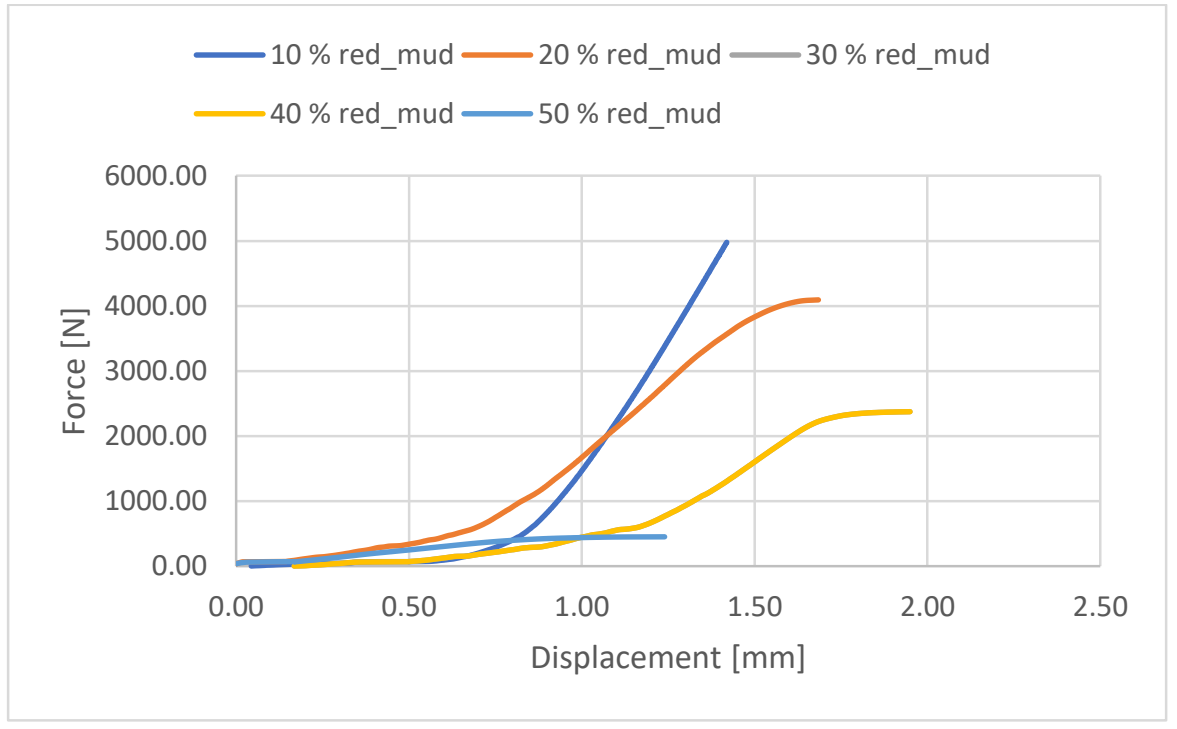

Figure 12. The average force applied by compaction test to bricks with different composition as a function of displacement 
As the different series contained different components (red mud, clay) in different proportions, the question may arise as to how each component modifies the properties of the specimens. Before embarking on more detailed analyses or even interpreting the results of compressive strength measurements, it is worth examining each series only visually. The clearest statement that can be made by comparing the 6 samples above (Figure 9) is that with the increase of the red mud content the appearance of the characteristic reddish colour increases (caused by iron oxide content). Summarizing the results of the tests (Figure 13) it can be clearly seen that the compressive strength of the bricks decreases with the increase of the red mud content.

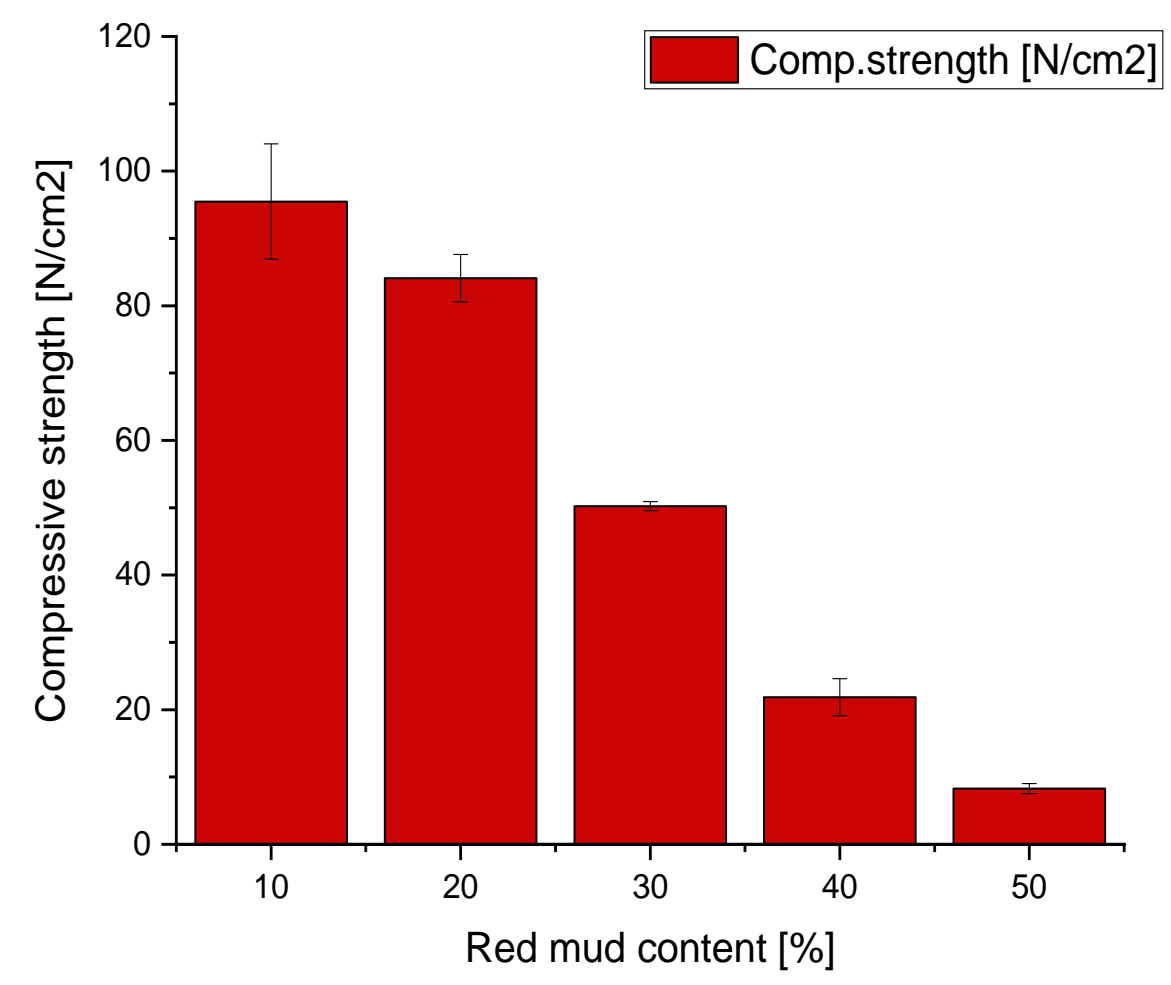

Figure 13. Relationship between red mud content and compressive strength

To support this statement, a so-called one-way analysis of variance was performed, the essence of which is that only one factor is considered in the calculations. In this type of analysis, the effect of a factor on the quantitative development of the dependent variables is examined (Samuels and Gilchrist, 2014). As part of the analysis, the so-called significant difference was calculated, which shows the deviation from the mean of the treatments. This is usually given a certain level of probability, which in this case is (and usually is) 5\%. Based on this, during the analysis of variance, the corresponding numerical value is marked as a boundary line, so a larger deviation from this is considered a significant difference. In the present case, this value is $13,06 \mathrm{~N} / \mathrm{cm}^{2}$. According to $\mathrm{SD}_{5 \%}$ there is no significant difference only in the case of bricks containing 10 and $20 \%$ red mud. In all other cases significant difference can be observed. From this it can be concluded that with a larger proportion $(30,40,50 \%)$ increase in the amount of red mud, the compressive strength of the bricks decreases significantly. 


\section{Summary}

The aim of the studies was to investigate the use efficiency of red mud in the brick industry. As part of the research, a unique set of tools was used during the preparation processes, with the help of which we made the production of the test specimens more efficient. In addition to tool development, existing laboratory machines (hydraulic press, furnace, hammer crusher, etc.) were also used.

As the first phase of the brick-making processes, the effect of compaction work on specimens was investigated. After preparing several series of specimens, it can be stated that manual pressing is not sufficient to produce bricks, as this results in non-shape-retaining and reproducible samples. In order to facilitate the consolidation of the bricks, it is essential to operate the hydraulic press efficiently, as the elimination of compression errors is essential for the research to move to the next phase.

As the amount of red mud increases, the porosity and number of cracks in the bricks increase, thereby reducing their load-bearing capacity, compression strength. To avoid this destructive effect, it would be advisable to use other additives and to determine an optimal red mud content.

\section{Acknowledgements}

The described article/presentation/study was carried out as part of the EFOP-3.6.1-16-2016-00011 "Younger and Renewing University - Innovative Knowledge City - institutional development of the University of Miskolc aiming at intelligent specialisation" project implemented in the framework of the Széchenyi 2020 program. The realization of this project is supported by the European Union, cofinanced by the European Social Fund."

\section{References}

[1] Németh, B. (2013): Ipari technológiák, Tankönyvtár, pp. 122-125.

[2] Schwarz, H.G. (2004): Aluminum Production and Energy, pp. 83. https://doi.org/10.1016/B0-12-176480-X/0037-7

[3] Power, G., Gräfe, M., \& Klauber, C. (2011) Bauxite residue issues: I. Current management, disposal and storage practices. Hydrometallurgy, 108(1-2), pp 44. https://doi.org/10.1016/j.hydromet.2011.02.006

[4] Akcil, A., Akhmadiyeva, N., Abdulvaliyev, R., Meshram, A. \& B. (2017): Overview On Extraction and Separation of Rare Earth Elements fromRed Mud: Focus on Scandium, Mineral Processing and Extractive Metallurgy Review, pp. 1. https://doi.org/10.1080/08827508.2017.1288116

[5] Wang, S., Ang, H.M., Tadé, M.O. (2008): Novel applications of red mud as coagulant, adsorbent and catalyst for environmentally benign processes, pp. 1622. https://doi.org/10.1016/j.chemosphere.2008.05.013

[6] Lima, M.S., Thives, L.P., Haritonovs, V., Bajars, K., (2017): Red mud application in construction industry: review of benefits and possibilities, IOP Conf. Series: Materials Science and Engineering 251, pp. 3. https://doi.org/10.1088/1757-899X/251/1/012033

[7] Shakir, A., Mohammed, A. (2013). Manufacturing of Bricks in the Past, in the Present and in the Future: A state of the Art Review. International Journal of Advances in Applied Sciences. 2. https://doi.org/10.11591/ijaas.v2i3.1751 
[8] Dalkılıç, N., Nabikoğlu, A. (2017). Traditional manufacturing of clay brick used in the historical buildings of Diyarbakir (Turkey). Frontiers of Architectural Research. 6. https://doi.org/10.1016/j.foar.2017.06.003.

[9] Haupin, W. (2001): Aluminum Production and Refining. Encyclopedia of Materials: Science and Technology, 132-141. ISBN: 0-08-0431526 https://doi.org/10.1016/B0-08-043152-6/00029-2

[10] Tabereaux, A. T., Peterson, R. D. (2014): Aluminum Production. Treatise on Process Metallurgy, pp. 843. Hardcover ISBN: 9780080969510 https://doi.org/10.1016/B978-0-08-096988-6.00023-7

[11] Faitli, J., Gombkötő, I., Mucsi, G., Nagy, S., Antal, G. (2017): Mechanikai eljárástechnikai praktikum, Miskolci Egyetemi Kiadó, pp. 177.

[12] Szakács, H., Varga, Cs., Nagy, R. (2012): Polimerek méréstechnikája, Pannon Egyetem, pp.78.

[13] Samuels, P., Gilchrist, M. (2014): One-way Analysis of Variance (ANOVA), pp. 2-4.

[14] https://aluminium.org.au/how-aluminium-is-made/alumina-refining-chart/ (last download: 2021.02.21)

[15] https://www.gobrick.com/docs/default-source/read-research-documents/technicalnotes/9manufacturing-of-brick.pdf?sfvrsn=0_(last download: 2021.02.21) 